\title{
Pemanfaatan Information and Communication Technology bagi Pengembangan Guru Madrasah Sub Urban
}

\author{
M. Chodzirin \\ Universitas Islam Negeri Walisongo Semarang
}

\begin{abstract}
The seriousness of the school/madrasah in updating instructional media hampered by the incompetence of some teachers use ICT-based learning media as one way of presenting the material. Mastery and knowledge of information technology will facilitate the teacher in finding the source of learning, so that students will not get bored attend classes. ICT training has been able to change mindside teacher of the conventional learning becomes more interactive learning. Teachers are becoming more aware that the presence of technology is inevitable in the learning process. Rapid technological developments should be exploited so that teachers who emerges is a positive impact, and not vice versa. The use of technology can help the learning process becomes more effective and efficient, and fun.
\end{abstract}

Abstrak: Keseriusan sekolah/madrasah dalam memperbarui media pembelajaran terganjal dengan ketidakcakapan sebagian guru menggunakan media pembelajaran berbasis ICT sebagai salah satu cara dalam menyampaikan materi. Penguasaan dan pengetahuan terhadap teknologi informasi akan mempermudah guru dalam mencari sumber pembelajaran, sehingga peserta didik pun tidak akan merasa bosan dalam mengikuti pelajaran di kelas. Pelatihan ICT ini telah mampu merubah mindside guru dari proses pembelajaran konvensional menjadi pembelajaran yang lebih interaktif. Guru menjadi lebih sadar bahwa kehadiran teknologi tidak dapat dielakan dalam proses pembelajaran. Perkembangan teknologi yang pesat harus bisa dimanfaatkan guru supaya yang muncul adalah dampak positif dan bukan sebaliknya. Pemanfaatan teknologi dapat membantu proses pembelajaran menjadi lebih efektif dan efesien serta fun.

Kata Kunci: teknologi, informasi, pengembangan, guru 


\section{PENDAHULUAN}

Pembelajaran merupakan aspek fundamental yang sangat mempengaruhi out put pendidikan. Apabila guru dan pembelajaran dikelola dengan baik akan membawa pengaruh kepada peningkatan mutu pendidikan. Demikian pula sebaliknya, bila guru dan pembelajaran dikelola dengan tidak semestinya, akan berdampak pada penurunan mutu pendidikan secara lebih global. Konsekuensi dari itu, di era sekarang, pengembangan media pembelajaran menjadi sesuatu yang tidak terelakkan.Sekolah maupun madrasah berupaya secara insentif memperbarui dan melengkapi media pembelajaran. Bahkan demi mengejar hal itu, banyak diantara sekolah / madrasah melalui Rencana Anggaran dan Kegiatan Sekolah (RAKS)-nya rela mengucurkan dana yang terhitung besar. Hal ini mungkin bagian dari tuntutan masyarakat kepada satuan pendidikan yang menghendaki hadirnya pembelajaran berbasis ICT (Teknologi Informasi dan Komunikasi) di tempat mereka.Kebijakan ini, pada akhirnya juga memberikan pengaruh pada orang tua/ wali murid.Orang tua / wali murid dilibatkan dan dimintai sumbangan untuk menanggung juga pembiayaan pengadaan media pembelajaran berbasis ICT dengan jumlah yang lumayan besar. Naasnya, keseriusan sekolah/madrasah dalam memperbarui media pembelajaran terganjal dengan ketidakcakapan sebagian guru menggunakan media pembelajaran berbasis ICT sebagai salah satu cara dalam menyampaikan materi.

Guru merupakan pioner dan menjadi tolak ukur dalam dunia pendidikan, kualitas seorang guru menjadi acuan kualitas pendidikan itu sendiri. Seorang guru di zaman sekarang dituntut mampu untuk berkreasi dalam mengembangkan metode pembelajaran dalam rangka meningkatkan minat belajar peserta didik.di zaman yang serba terbuka sekarang ini seorang guru harus mampu memanfaatkan kemajuan dan kecanggihan teknologi terutama teknologi informasi. Seorang guru tidak boleh hanya berkutat dengan buku sebagai satu-satunya sumber pembelajaran, tetapi seorang guru harus mampu mencari sumber lainnya melalui Internet atau melalui teknologi informasi lainnya.

Dalam kehidupan manusia di era global saat ini, manusia akan selalu berhubungan dengan teknologi. Teknologi menurut Smaldino pada hakikatnya adalah alat untuk mendapatkan nilai tambah dalam menghasilkan produk yang bermanfaat. 'Teknologi sekarang ini perkembangannya sudah sangat pesat. Alvin Toffler dalam Munir menggambarkan perkembangan tersebut sebagai sebuah

${ }^{1}$ Heinich, Moelenda, Russel, Smaldino, Instructional Media anf Technologies for Learning, Merril an Imprint of Prentice hall englewood cliff, (New Jersey: Ohio, 2008), hlm. 12. 
revolusi yang berlangsung dalam tiga gelombang yaitu, gelombang pertama dengan munculnya teknologi dalam pertanian, gelombang kedua munculnya teknologi industri dan gelombang tiga munculnya teknologi informasi yang mendorong tumbuhnya komunikasi.Ketiga perkembangan tersebut telah berhasil menguasai dan mempengaruhi kehidupan manusia di dunia. ${ }^{2}$ Sehingga jika "gagap" teknologi maka akan dapat tertinggal untuk memperoleh kesempatan untuk maju. Informasi dan telekomunikasi telah memiliki peran yang amat sangat penting dan nyata, apalagi masyarakat saat ini sedang menuju kepada masyarakat ilmu pengetahuan.

Penguasaan dan pengetahuan terhadap teknologi informasi akan mempermudah guru dalam mencari sumber pembelajaran, sehingga peserta didik pun tidak akan merasa bosan dalam mengikuti pelajaran di kelas. Seorang guru yang mampu mengembangkan metode pembelajaran yang variatif dan mampu menghadirkan ataupun memberi materi-materimpelajaran yang kreatif dan variatif secara otomotis akan mampu dan sukses menampilkan suasan pembelajaran yang menarik yang membuat peserta didik merasa betah di dalam kelas.

Di era informasi ini, tanpa adanya kemauan untuk mengerti, menggunakan, dan mengakses bidang yang relevan dengan keilmuannya maka fungsi guru sebagai fasilitator perkembangan ilmu akan tereduksi yang lamalama bisa jadi hilang, sehingga yang ada hanyalah guru yang miskin informasi. Disamping itu keharusan guru dalam mendorong dan mendukung siswa kearah kreatif pemanfaatan ICT mutlak dilaksanakan.Untuk itu peranan guru sangat dibutuhkan demi keseimbangan penguasaan dan pengemasan informasi yang bakal dihadapkan dan disajikan kepada siswanya.Karena ada kemungkinanan siswa telah memahami lebih jauh satu persoalan dari pada gurunya.

Seorang guru dituntut untuk menguasai teknologi informasi atau dalam kata lain seorang guru dilarang untuk Gaptek. Jangan sampai seorang guru kalah dengan para peserta didiknya dalam penguasaan terhadap Teknologi Informasi. Tapi yang terjadi adalah banyak guru yang belum paham akan pentingnya penguasaan terhadap Teknologi Informasi sehingga membuat mereka belum mau untuk meningkatkan kemampuan dalam penguasaan Teknologi Informasi tersebut. Banyak guru yang merasa bahwa dengan kemampuan yang telah mereka miliki, menjadikan mereka merasa tidak perlu lagi dalam meningkatkan

2 Munir, Pembelajaran Jarak Jaub berbasis Teknologi Informasi dan Komunikasi.(Bandung: Alfabeta, 2011), hlm. 29. 
kemampuan pengetahuan mereka dengan berbagai macam alasan, terutama alasan usia dan tidak adanya anggaran atau tidak adanya bantuan dari pemerintah untuk menyediakan fasilitas tersebut.

Permasalahan penguasaan teknologi informasi lebih banyak dialami oleh guru yang ada di madrasah sub urban. Madrasah sub urban ini cenderung berlokasi di pinggiran atau pedesaan yang notabene juga tidak terlalu jauh dari pusat kota. Salah satunya adalah Madrasah Tsanawiyah Darul Ulum yang terletak di desa Wates Ngaliyan Semarang.Wilayah Ngaliyan termasuk sub urban dari sentral urban Semarang. Sebagai madrasah swasta, madrasah ini merupakan salah satu madrasah yang sedang berkembang.Meskipun begitu tidak banyak siswa yang masuk ke madrasah tersebut, hanya sekitar 30 sampai 50 siswa per tahun.Itupun berasal dari masyarakat sekitar. Mereka belajar dengan sarana prasarana yang terbatas.Pihak madrasah mengenakan biaya pendidikan yang murah, mengingat mayoritas siswa berlatar belakang kelas menengah-bawah. Secara kelembagaan madrasah swasta tersebut berada dalam pengelolaan yayasan yang memiliki sumber daya terbatas.Keterbatasan tersebut sebagai konsekuensi dari tumbuh dan berkembangnya yayasan dari inisiatif masyarakat lokal di kawasan tersebut.Inisiasi tersebut tentu dilatar belakangi oleh kondisi sosial ekonomi masyarakatnya yang serba terbatas pula. Pada sisi lain banyak warga masyarakatnya yang membutuhkan pendidikan formal yang murah dan terjangkau untuk meningkatkan kualitas sumber daya manusia. Meskipun ratarata guru yang mengajar di madrasah tersebut adalah lulusan sarjana namun penguasaan guru terhadap ICT sangat kurang.Dalam rangka peningkatan kualitas pembelajaran, maka guru perlu dibekali dengan penguasaan ICT supaya kualitas pembelajaran bisa meningkat, dan muara akhirnya adalah peningkatan kualitas madrasah.

\section{URGENSITAS ICT DALAM PROSES PEMBELAJARAN}

Tantangan guru di abad ke-21akan semakin kompleks, oleh karena itu guru perlu melihat karakteristik masyarakat di era gloablisasi ini berkaitan dengan perannya di dalam pendidikan. Menurut Tilaar ada tiga karakteristik masyarakat di abad ke-21 yaitu : Pertama, Masyarakat Teknologi, maayarakat yang melek teknologi dan menggunakan berbagai aplikasi teknologi sehingga dapat mengubah cara berfikir dan bertindak bahkan mengubah bentuk pola hidup yang berlainan dengan pola hidup sebelumnya. Pada masyarakat ini, peran pendidikan sangat strategis terutama dalam memberikan dorongan, bimbingan dan motivasi, semangat serta fasilitas pendidikan bagi peserta didik untuk mengembangkan kemampuannya untuk mendapatkan pengetahuan dan 
teknologi. Pendidikan berperan dalam memberikan arahan dan bimbingan agar penguasaan teknologi tidak menjadi bumerang bagi masyarakat karena kurangya penghayatan terhadap etika dan moral. Disinilah peran guru itu sendiri harus menguasai teknologi agar dapat memberikan pengetahuan dan teknologi terkini kepada peserta didik.

Kedua, Masyarakat Terbuka, dengan semakin luasnya penggunaan teknologi informasi dan komunikasi melahirkan masyarakat yang terbuka. Adanya masyarakat terbuka, maka tidak menutup kemungkinan antara satu bangssa yang satu dengan bangsa yang lain akan berkompetisi. Untuk itu diperlukan manusia yang mampu mengembangkan kemampuan dan kapasitasnya menjadi manusia dan bangsa yaang kuat, ulet, kreatif dan disiplin sehingga tidak akan tertindas oleh kompetisi.

Ketiga, Masyarakat Madani, masyarakat yang menghormati dan saling menghargai satu dengan yang lain, mengakui hak-hak asasi manusia, menghormati prestasi individu dan masyarakat turut andil bertanggung jawab dalam kelangsungan hidup dari masyarakatnya dan meyakini nilai-nilai etis yang diyakini kebenarannya.

Mewujudkan masyarakat yang cerdas, diperlukan proses pendidikan yang bermutu dan kunci utama mutu pendidikan adalah mutu guru. Proses pedidikan pada masyarakat abad ke-21 adalah interaksi guru dengan siswa sesuai dengan kemajuan ilmu pengetahuan dan teknologi dalam demokratis masyarakat dan terbuka. Masyarakat yang demikian ini, menuntut adanya pelayanan yang profesional dari pelakunya yaitu guru. Dengan demikian guru harus dapat meningkatkan profesionalismenya sebagai seorang guru dan pelaksanaan profesionalistasnya dalam bentuk kompetensi guru di sekolah.

Tuntutan bagi seorang guru pada abad ke-21 ini adalah penguasaan kompetensi yang memfasilitasi belajar siwa sesuai dengan hasil belajar yang menjadi syarat. Menurut American Association College of Teacher Education (AACTE) dinyatakan bahwa guru abad ke-21 hendaknya dapat :1) Sukses menggabungkan antara teknologi dengan pedagogik dan materi pelajaran serta dapat mengembangkan kreativitas dalam menggunakan teknologi yang sesuai dengan tuntutan pelajaran yang dibutuhkan, 2) Menggabungkan pembelajaran sesuai dengan kurikulum dan tuntutan di abad 21,3) Adanya keseimbangan strategi pembelajaran dengan metode pembelajaran berbasis masalah dan proyek, 4) Penguasaan berbagai model assesmen atau penilaian, 5) Bertindak sebagai mentor, 6) Meningkatkan keprofesionalannya sebagai guru.

Pendidikan global yang mengarah pada general knowledge product bagi siswa, mengharuskan pembelajaran dilakukan dengan berkolaborasi berbasis 
Teknologi Informastika Komputer. ICT atau information dan communication Technology (ICT) adalah teknologi yang menyimpan, menghasilkan dan mengolah serta menyebarkan informasi. Melihat fungsi dari ICT tersebut, maka teknologi ini sangat di perlukan dalam peningkatan mutu pembelajaran di sekolah. Diharapkan dengan penggunan teknologi ini, maka siswa akan memiliki kemampuan berfikir yang kritis dalam memecahkan berbagai permasalahan.

Untuk itu penguasaan teknologi dan model pembelajaran sangat penting bagi guru karena merupakan inovasi bagi guru dalam pembelajaran. Integrasi teknologi informasi komputer dalam pembelajaran dapat dimaknai sebagai mempelajari teknologi dalam pembelajaran untuk mensupport, sekaligus suplemen serta mempeluas keterampilan siswa dalam belajar.

Untuk dapat memanfaatkan ICT dalam proses pembelajaran dan memperbaiki mutu pembelajaran, ada tiga hal yang harus diperhatikan, pertama, Siswa dan guru harus memiliki akses teknologi digital dan internet dalam kelas, sekolah dan lembaga pendidikan guru. Kedua, Harus tersedia materi yang berkualitas, bermakna dan dukungan kutural bagi siswa dan guru. Dan ketiga, 3)Guru harus memiliki pengetahuan dan ketrampilan dalam menggunakan alatalat dan sumber-sumber digital untuk membantu siswa agar mencapai standar akademik.

Penggunaan ICT dalam proses belajar dan pembelajaran merupakan salah satu media yang dapat digunakan oleh guru. Penggunaan ICT dalam pembelajaran menjadi sangat penting pada saat ini dengan berkembang pesatnya ilmu pengetahuan dan teknologi. Dengan menggunakan bantuan ICT maka guru akan dapat mengetahui perkembangan informasi di wilayah lain sehingga dapat menunjang materi pembelajaran. Melalui ICT siswa akan dapat memperoleh informasi refensi yang terkait dengan tugas-tugas di sekolah dan sebagai tambahan bahan pembelajaran.

Kemajuan ICT sangat membatu bagi peningkatan profesionalisme guru, namun ada juga beberapa hal yang perlu diwaspadai.Pertama, informasi yang tersaji di laman-laman internet bermacammacam komunikasi elektronik, budaya ICT telah menunjukkan kekuatannya. Internet memang sudah ada sejak 1969, tetapi dampaknya menjadi luar biasa setelah ditemukannya World Wide Web pada tahun 1989 oleh Tim Berners-Lee dan diimplementasikan tahun 1991.3

Internet menjadi sumber informasi bagi semua orang yang menginginkannya. Dengan tekologi mutakhir ini, telah pula berkembang pembelajaran berbasis komputer dan berbasis ICT, yang membantu upaya

${ }^{3}$ http://en.wikipedia.org/wiki/Information Age 
memotivasi guru dalam memilih bahan ajar pada proses belajar mengajar juga membantu para pelajar melalui kemasan informasi yang memikat, lengkap dengan gambar berwarna dan bergerak, baik gambar nyata maupun animasi. Model pembelajaran ini tentu selaras dengan lingkungan ber-TIK di luar sekolah sehingga memotivasi pelajar untuk belajar.Kita juga bisa menyaksikan bahwa di Indonesia Peradaban V ini diwarnai dengan penggunaan hand-phone yang sangat luar biasa luas, menjangkau semua kelompok umur.Komunikasi antar manusia sangat lancar tanpa kendala ruang dan waktu, benar-benar instan. Kapasitas memori mesin HP yang makin besar mampu memuat data yang besar pula, termasuk pertunjukan musik dan gambar hidup bersama suaranya. Pelajaran sebagian besar dilaksanakan dengan ICT, peserta didik akan kehilangan kesempatan untuk mengembangkan keterampilan interaktif dan komunikasi tatap muka dan belajr memecahkan masalah dan bersosialisasi. Semua ini menjadi tantangan bagi dunia pendidikan kita, yang menjadi sarana mencerdaskan kehidupan bangsa.Singkatnya, teknologi dalam tidak dapat mengambil alih peran guru.

TIK untuk Memfasilitasi Pendidikan dalam Menjalankan Fungsi dan Mencapai Tujuannya Seperti telah disebut dalam pengantar, pendidikan tidak terjadi dalam ruang hampa, melainkan dalam dunia nyata. Oleh sebab itu Dalam memanfaatkan ICT untuk tujuan pendidikan diperlukan kesadaran akan ciriciri abad ke-21 ini, yang akan membantu dalam penentuan langkah kependidikan yang tepat, termasuk dalam merancang pemanfaatan ICT. Di sini peran guru sangat penting dimana guru melakukan pendekatan konstruktif yaitu peserta didik di tempatkan pada posisi yang memiliki kemampuan belajar, sehingga peran guru adalah sebagai pelatih, pemandu, dan pendorong di sat di perlukan oleh peserta didik.

ICT dalam pendidikan hendaknya mempertimbangkan karaktersitik peserta didik, pendidik, dan tenaga kependidikan dalam keseluruhan pembuatan keputusan ICT. ICT hendaknya dirancang untuk memperkuat minat dan motivasi pengguna untuk menggunakannya semata guna meningkatkan dirinya, baik dari segi intelektual, spiritual (rohani), sosial, maupun ragawi. ICT hendaknya menumbuhkan kesadaran dan keyakinan akan pentingnya kegiatan berinteraksi langsung dengan manusia (tatap muka), dengan lingkungan sosialbudaya (pertemua, museum, tempat-tempat bersejarah), dan lingkungan alam (penjelajahan) agar tetap mampu memelihara nilai-nilai sosial dan humaniora (seni dan budaya), dan kecintaan terhadap alam sebagai anugerah dari Tuhan Yang Maha Esa. 
ICT hendaknya menjaga bahwa kelompok sasaran tetap dapat mengapresiasi teknologi komunikasi yang sederhana dan kegiatan-kegiatan pembelajaran tanpa ICT karena tuntutan penguasaan kompetensi terkait dalam rangka mengembangkan seluruh potensi siswa secara seimbang.ICT hendaknya mendorong pengguna untuk menjadi lebih kreatif dan inovatif sehingga tidak hanya puas menjadi konsumen informasi berbasis ICT. Jika guru dapat melaksanakan pemanfaatan ICT tersebut dapat diterapkan bersama prinsipprinsip di atas, niscaya dampak positif akan dapat diperoleh secara optimal dan dampak negatifnya akan terkendali sampai titik minimal.

Guru sebagai sumber daya pendukung. Pemanfaatan ICT memerlukan dukungan tenaga manusia, perangkat lunak, dan perangkat keras (peralatan), serta biaya. Tenaga manusia mencakup guru dan teknisi ICT bersama kompetensinya, perangkat lunak merujuk pada program ICT yang telah dirancang sesuai tujuan yang akan dicapai dengan ICT terkait, perangkat keras merujuk pada peralatan ICT bersama dengan tempat yang kuat dan aman untuk meletakkan dan menyimpan ICT, sedangkan biaya mencakup biaya untuk pemeliharaan peralatan, peremajaan peralatan, dan pengembangan program serta pemberdayaan tenaga manusianya.

Menurut Jumali, dkk (2004: 39) dalam arti sederhana pendidik adalah semua orang yang dapat membantu perkembangan kepribadian seseorang dan mengarahkannya pada tujuan pendidikan. Tugas dari pendidik adalah membimbing, mengajar dan melatih peserta didik.

Guru yang profesional mampu mengembangkan semua sarana prasarana yang digunakan dalm pembelajaran. Selalu dapat meningkatkan dan menciptakan sebuah inovasi dalam pembelajaran agar tidak membosankan diantaranya dengan penggunaan ICT yang dikuasai sehingga pembelajaran akan lebih bermakna bagi siswa. Profesionalisme yang berarti suatu pekerjaan atau pencaharian yang mempunyai keahlian.Secara harfiah dapat diartikan dengan suatu pekerjaan yang memerlukan keahlian dan ketrampilan tertentu, dimana keahlian dan ketrampilan tersebut didapat dari suatu pendidikan atau pelatihan khusus.

Dewasa ini perkembangan dan kemajuan teknolgi informasi berjalan sangat cepat.Seiring dengan perkembangan teknologi informasi, penyimpanan dan pengiriman data semakin murah dan semakin baik kualitasnya.Baik individu, institusi, maupun pemerintah ikut melakukan berbagai upaya untuk memanfaatkan perkembangan teknologi informasi ini.Bahkan dalam dunia pendidikan, sudah saatnya kita memanfaatkan teknologi informasi tersebut.Dalam dunia pendidikan perkembangan teknologi informasi mulai 
dirasa mempunyai dampak yang positif karena dengan berkembangnya teknologi informasi dunia pendidikan mulai memperlihatkan perubahan yang cukup signifikan. Banyak hal yang dirasa berbeda dan berubah dibandingkan dengan cara yang berkembang sebelumnya. Saat sekarang ini jarak dan waktu bukanlah sebagai masalah yang berarti untuk mendapatkan ilmu, berbagai aplikasi tercipta untuk memfasilitasinya.

Pemanfaatan media ICT dalam bidang pendidikan dapat menunjang pembelajaran yang kini merupakan suatu keharusan, bukan hanya untuk meningkatkan efektivitas dan kualitas pembelajaran, tetapi yang lebih penting adalah untuk meningkatkan penguasaan ICT baik bagi guru maupun siswa sebagai bekal hidup di era teknologi yang terus berubah dan berkembang. Dalam konteks pembelajaran, pemanfaatan dan pemberdayaan media ICT, termasuk teknologi multimedia, dapat meningkatkan efektivitas dan efisiensi pembelajaran, yang diharapkan dapat memberikan kepuasan public dengan memberikan layanan yang prima dengan hasil sesuai dengan Standar dan tujuan yang diharapkan. Jika pada masa lalu ada anggapa bahwa pembelajaran tidak terlalu perlu menggunakan media ICT, pada era saat ini penggunaan media ICT merupakan suatu keharusan.

Penguasaan Teknologi Informasi dan Komunikasi kini menjadi bagian dari tuntutan kompetensi guru, baik guna mendukung pelaksanaan tugasnya maupun sebagai sarana untuk mencari dan mengunduh sumber-sumber belajar.Sehingga setiap guru pada semua jenjang harus siap untuk terus belajar ICT guna pemenuhan tuntutan kompetensi tersebut.

Di era informasi kini, sudah tidak zaman lagi para guru gagap terhadap teknologi.Teknologi diharapkan menjadi kesatuan dalam pembelajaran sehingga tercipta peserta didik yang lebih aktif dan mandiri. Guru juga perlu memiliki kompetensi profesional yaitu selalu meningkatkan dan mengembangkan kualifikasi akademik dan kompetensi secara berkelanjutan sejalan dengan perkembangan ilmu pengetahuan, teknologi dan seni.

Pelaksanaan UKG yang baru-baru ini dilaksanakan secara online merupakan salah satu bentuk dari perkembangan teknologi informasi.Banyak sekali para guru yang khawatir dan resah dalam pelaksanaan UKG yang berbasis online ini dikarenakan minimnya pengetahuan tentang penggunaan ICT. Sebagian dari mereka gaptek tentang bagaimana cara menggunakan komputer beserta alat-alat pendukungnya. Sehingga mereka perlu mengikuti ujicoba terlebih dahulu dalam penggunaannya. Perlunya guru dilatih ICT karena, TIK dapat digunakan untuk membantu pekerjaan administrative, TIK dapat digunakan untuk membantu mengemas bahan ajar (Multimedia), TIK dapat 
digunakan untuk membantu proses manajemen pembelajaran, dan TIK dapat digunakan untuk dukungan teknis dan meningkatkan pengetahuan agar dapat mewujudkan self running creation.

Dalam rangka menyesuaikan diri dengan kemajuan IPTEK dan era globalisasi, berbagai upaya telah ditempuh pemerintah untuk mengadakan pembaharuan dan peningkatan mutu pendidikan, yang tercermin dalam berbagai kebijakan. Salah satu kebijakan pemerintah antara lain dalam bentuk pembaharuan atau perubahan kurikulum, yang tentunya menuntut guru dan sekolah untuk lebih aktif dan kreatif mengadakan penyesuaian. Dalam menanggapi berbagai kebijakan pemerintah itu, hampir semua sekolah merespon secara positif melalui berbagai tindakan, seperti; 1) Mengirim guru untuk mengikuti kegiatan pelatihan, penataran, seminar dan workshop mengenai ICT. 2) Mengadakan kegiatan pelatihan dan sosialisasi bagi seluruh guru dengan mendatangkan nara sumber. 3) Melengkapi berbagai sarana dan media yang dapat menunjang kegiatan pembelajaran. 4) Melaksanakan pembelajaran dengan menggunakan berbagai strategi dan metode, meskipun tidak semua sekolah mampu melaksanakan secara efektif. 5) Mengadakan studi banding ke sekolah lain yang dipandang lebih maju.

Namun pada kenyataannya dilapangan masih banyak guru yang yang gagap teknologi dikarenakan mereka beranggapan bahwa pembelajaran tidak perlu menggunakan media ICT selain itu terkadang pihak sekolah mengirim guru yang sudah mahir dalam ICT, sehingga guru yang gaptek tidak mempunyai kesempatan untuk menggali ilmu tentang ICT.Para guru banyak yang terjebak pada metode pembelajaran konvensional.Padahal, kemajuan teknologi seperti internet bisa jadi sumber belajar yang menolong guru untuk meningkatkan kualitas pembelajaran di kelas.Namun masih banyak guru-guru yang gaptek khususnya guru-guru senior.

Agar ICT terus digunakan oleh guru maka manfaat pelatihan harus sesuai dengan kebutuhan untuk mengatasi permasalahan sehari-hari, karena kalau tidak maka ketrampilan teknis yang dimiliki akan mudah terlupakan. Untuk itu seiring dengan peningkatan kompetensi guru maka sekolah harus memiliki program pemanfaatan ICT yang memaksa beserta aturan reward \& punishment nya. Agar guru mau menggunakan ICT maka perlu didiskripsikan secara jelas dahulu kemanfaatan ICT tersebut secara personal bagi tiap guru, bukan hanya kemanfaatan bagi sekolah atau pihak lain. ${ }^{4}$

\footnotetext{
Siti Sholehani, Pentingnya Penguasaan TIK bagi Guru, http://pendidikan.probolinggokab.go.id/ pentingnya-penguasaan-tik-bagi-guru/
} 


\section{KENDALA GURU DALAM PENGUASAAN ICT}

Beberapa kendala yang dihadapi guru dalam pemanfaatan ICT adalah adanya kendala internal, seperti kesibukan jam mengajar di berbagai tempat, maupun kendala eksternal seperti ketersediaan akses internet dan waktu pelatihan sendiri.

Kendala internal dan eksternal tersebut sebenarnya hanyalah sebuah "pembenaran" untuk tidak melakukan hal-hal yang dibutuhkan. Artinya, berpatokan pada peribahasa "dimana ada kemauan disitu ada jalan" kita memang harus mempersiapkan diri menyongsong era baru dalam berkomunikasi dengan berbagai informasi yang ada.Menurut Bona Simanjuntak,Aktivis Jaringan Informasi Sekolah (JIS), di salah satu kecataman di Deli Serdang, internet dan komputer menjadi barang yang terlalu mahal dan langka. Ia dan rekannya telah menggelar training on trainers (TOT) bagi guru-guru di kawasan sekolah kejuruan (SMK), dimana rasio komputer dengan siswa di daerah tersebut mencapai 1:100, artinya satu komputer untuk melayani kebutuhan 100 guru.

Guru terpaksa mengajar komputer dengan imajinasi dan penjelasan verbal saja, kendala ini disebabkan oleh tidak adanya fasilitas komputer sungguhan untuk digunakan siswa, padahal belajar komputer lebih efektif melalui praktek.

Kendala para guru dalam penggunaan komputer dan ICT adalah ketidakmampuan guru dalam berbahasa inggris, dimana bahasa inggris sangat dominan dipakai dalam pengoperasional komputer dan ICT.Hal ini ditekankan mengingat guru punya andil besar dalam mencerdaskan anak bangsa.

Beberapa siswa mengaku merasa lebih lihai (pandai) dalam hal penggunaan telepon seluler, ini terbukti dalam berbagai rasia yang dilakukan oleh sekolah terhadap gambar porno maupun video porno yang ada di ponsel siswa, ternyata banyak yang lolos, tak terdeteksi, mengingat guru banyak yang tidak pengalaman dalam hal pemakaian ponsel yang canggih daripada siswanya. Mungkin ini disebabkan oleh daya beli guru terhadap model HP lebih rendah dari pada orang tua siswa dalam beberapa kasus.Ini sebenarnya kendala yang yang tidak kentara bagi guru dalam hal pemanfaatan ICT kaitannya dengan penggunaan ponsel oleh siswa.

Menurt Doni B.U., Msi., kini telah ada kesenjangan digital sebagai isu science fiction semata yang diciptkan oleh sekelompok ekslusif manusia pemuja teknologi informasi, atau ada menyebut sebagai digital divide. Menurutnya kesenjangan digital akhirnya hanya dipahami sebagai gap antara pemilik/ pengguna teknologi (the haves) dan mereka yang tidak memiliki atau mengunakan teknologi.Kaum the have diyakini sebagai pihak pertama yang 
mengada-ada adanya istilah kesenjangan teknologi yang mengkontraskan kelompok kedua.Hal ini bisa menimbulkan rasa pesimistik bagi para guru dalam penggunaan dan pemanfaatan ICT.

Guru kadang dituntut agar cepat beradaptasi dengan misi dan visi institusi yang menurut pemahamannya terlalu berat bagi guru, karena tidak memulai dari tahapan yang tepat dalam peningkatan penguasaan penggunaan ICT bagi guru, sementara tuntutan dan target sekolah ke jenjang nasional, bahkan internasional sebagai hal yang kontradiktif.

Guru dihadapkan pada bayangan bahwa pemanfaatan komputer dapat mempermudah keperluan hidup, sementara pada sisi lain dimunculkan isu bahwa penggunaan komputer adalah sebagai apresiasi penghargaan terhadap para genius man yang membuat komputer itu sendiri. Ini kedengaran lucu memang, ada orang mengatakan menggunakan komputer itu identik sebagai bentuk menglarisi produk komputer.Ini gawat, guru bisa pasif dan apatis dalam pemanfaatan ICT.

Masih ada guru yang beranggapan tidak menggunakan komputer dan ICT dalam proses pembelajaran bukan hal mengganggu jalannnya pelajaran, karena guru merasa tidak mendapatkan fasilitas komputer saat mengajar, jadi inilah yang membuat mereka merasa tidak perlu untuk tahu cara menggunakan komputer. Kasus ini terjadi pada guru-guru yang sudah berusia tua, walaupun yang guru yang yunior pun masih ada yang gagap pada kemanjuan ICT.

Dilema yang muncul di lapangan, dari berbagai upaya yang telah dilaksanakan untuk membantu para guru mengenala ICT, terganjal di tengah jalan, penyebabnya adalah; 1) takut akan kesalahan yang diperbuat, sehingga dapat mengakibatkan kerusakan media; 2) merasa usianya sudah tua, sehingga kurang bermanfaat bagi dirinya; 3) kurang memahami bahasa teknik TI (bahasa inggris); 4) banyaknya rutinitas di luar pelajaran ICT.

Selama ini tenaga pendidik hanya lebih banyak disuguhi berbagai diklat, pelatihan dengan materi yang berkisar pada kurikulum, pakem (contextual learning), MBS (manajemen berbasis sekolah) dan materi lain yang berhubungan langsung dengan tugas guru di kelas. Jarang ada pelatihan guru yang bersifat pembekalan tentang suatu ketrampilan atau keahlian khusus, misalnya aplikasi ICT, padahal pelatihan seperti ini tidak kalah penting dan bermanfaat bagi guru, terutama guru yang masih gagap teknologi.Menurutnya ada beberapa faktor yang menjadikan para guru masih gagap ICT, pertama, Lokasi, bagi guru yang mengajar di daerah terpencil, teknologi canggih seperti komputer bukanlah sesuatu yang urgen untuk dikuasai karena kebutuhan untuk menggunakan sangat rendah.kedua, kesadaran yang asih rendah mengenai mengenari ati penting 
teknologi untuk menunjang profesi guru dalam menyelesaikan tugas, Ketiga, tidak adanya eksempatan dan peluang untuk bisa lebih dekat dengan teknologi canggih.

Faktor penghambat guru dalam memanfaatkan ICT adalah pertama, ketidakadanya komputer baik laptop maupun PC sehingga dirasa masih belum seimbang peralatan yang disediakan di sekolah sementara komputer pribadi belum punya.Kedua, adalah faktor penghampat yang ada hubungannya dengan rasa malas karena tidak adanya waktu untuk mempelajari. Ini terjadi karena guru yang baik dan benar harus menguasai 10 kompetensi guru, waktu 24 jam masih kurang karena banyaknya kewajiban yang hrus dipenuhi.

\section{PEMANFAAT ICT BAGI GURU MADRASAH SUB URBAN}

Langkah awal yang dilakukan dalam melakukan karya pengabdian ini adalah dengan melakukan identifikasi kebutuhan.Identifikasi kebutuhan dilakukan komunikasi dengan pihak madrasah (dalam hal ini kepala madrasah) terkait dengan implementasi ICT yang dibutuhkan oleh guru. Identifikasi ini perlu dilakukan supaya pengabdian yang akan dilakukan lebih efektif dan tepat sasaran. Mengingat ada beberapa guru yang sudah memiliki kompetensi ICT meskipun untuk hal-hal yang dasar.

Hasil identifikasi menunjukan bahwa ternyata Guru belum begitu menguasai program Microsoft Power Point (khususnya power point interaktif). Dan Perlu pendalaman Microsoft Excel (formulas \& mail merger) bagi guru.

Kedua program tersebut menurut Mustofa, seorang kepala madrasah, sangat diperlukan oleh guru. Selama ini guru jangan menggunakan powerpoint dalam proses pembelajaran. Kalaupun ada guru yang menggunakan powerpoint, bentuknya juga sangat sederhana. Sehingga perlu ada peningkatan kompetensi ini, mengingat program powerpoint ini dapat membantu guru dalam penyampaian materi pelajaran. Jika dikemas lebih menarik, program power point dapat menarik minat siswa dalam mempelajari materi baik ketika berada di dalam kelas maupun saat belajar secara mandiri.Karena program power point interaktif tidak hanya disampaikan guru di dalam kelas, tetapi guru juga bisa meminta siswa untuk mempelajarinya secara mandiri di rumah.

Pola penyajian yang dapat digunakan diantaranya adalah stand alone. Daryanto (2006: 31) mengatakan stand alone adalah pola penyajian Microsoft Office Power Point yang dirancang khusus untuk pembelajaran individual yang bersifat interaktif. Setiap siswa dapat mempelajari materi pelajaran secara individual. Siswa dapat belajar sesuai dengan kemampuannya sehingga penggunaan Microsoft 
Office Power Point dengan pola penyajian stand alone diharapkan dapat meningkatkan hasil belajar siswa.

Keterbatasan akan adanya media seperti perangkat presentasi yang diperlukan sebagai alat yang mampu menampilkan informasi yang terdapat pada Microsoft Office Power Point dapat diatasi dengan menggunakan pola penyajian stand alone. Dengan bantuan media powerpoint, seorang guru dapat mempresentasikan materi ajar kepada siswa bisa lebih mudah dalam mentransformasikan ilmunya melalui presentasi yang diberikan oleh seorang guru kepada anak didiknya di kelas. Disamping memudahkan seorang guru menguasai kelas dan membantu anak-anak didik untuk tetap fokus dengan apa yang diterangkan oleh seorang guru.

Microsoft Power Point merupakan suatu software yang akan membantu dalam menyusun sebuah presentasi yang efektif, professional, dan juga mudah. Media powerpoint bisa membantu sebuah gagasan menjadi lebih menarik dan jelas tujuannya jika dipresentasikan karena media powerpoint akan membantu dalam pembuatan slide, outline presentasi, presentasi elektronika, menampilkan slide yang dinamis, termasuk clipart yang menarik, yang semuanya itu mudah ditampilkan di layar monitor komputer. Power Point adalah alat bantu presentasi, biasanya digunakan untuk menjelaskan suatu hal yang dirangkum dan dikemas dalam slide Power Point.Sehingga pembaca dapat lebih mudah memahami penjelasan kita melalui visualisasi yang terangkum di dalam slide.

Disamping program power point penguasaan guru terhadap program microsoft excel juga perlu ditingkatkan. Mengingat program ini sangat membantu guru, khususnya dalam menyelesaikan tugas-tugas administratif yang harus dikerjakan oleh guru, seperti dalam proses penilaian. Supaya proses penilaian berjalan dengan efektif guru perlu memahami seluk beluk program ini, khususnya yang terkait dengan pemanfaatan formula dan mail merger. Formula yang ada dalam program Microsoft exel dapat membantu guru dalam menyajikan komponen penilaian secara lebih mudah, seperti prosentase komponen penilaian, kriteria penilaian, maupun untuk menentukan tuntas atau tidaknya siswa dalam suatu mata pelajaran.

Microsoft Office Excel memang dikenal dengan penggunaan rumusrumus atau formula dalam lembar kerjanya. Penggunaan rumus yang efektif akan memudahkan guru dalam membuat laporan pekerjaan dengan menggunakan MS Excel. Formula atau rumus MS Excel adalah keunggulan tersendiri untuk aplikasi ini, dengan kemampuannya dalam mengolah data melalui perhitungan matematis yang sangat beragam fungsinya. 
Setiap rumus di dalam MS Excel memilik fungsi tersendiri.Oleh karena itu guru harus benar-benar memahami masing-masing fungsi dasarnya agar penggunaan rumus dalam MS Excel bisa lebih maksimal dan efisien.Jika telah paham fungsi dasarnya, guru bisa berkreasi dalam meracik rumus yang sesuai dengan kebutuhan data.

Salah satu fungsi pencarian dan referensi dalam MS Excel adalah VLOOKUP.Fungsi dapat membantu guru saat perlu menemukan berbagai hal dalam tabel atau rentang menurut baris. Misalnya, mencari nama belakang siswa menurut nomor induknya, atau menemukan nomor teleponnya dengan mencari nama belakangnya (sama seperti buku telepon).

Mengingat keunggulan kedua program tersebut, sehingga penulis memutuskan untuk memberikan pelatihan pemanfaatan power point dan Microsoft office excel dalam proses pembelajaran.

Langkah selanjutnya adalah Menjalin Kerjasama. Untuk mendukung keberhasilan karya pengabdian ini, dilakukan juga kerjasama dengan praktisi ICT, dalam hal ini berkerjasama dengan $\mathrm{RnD}$ Media Semarang yang juga konsen dengan implementasi ICT dalam pendidikan.

Kerjasama ini perlu dilakukan dalam rangka mendukung kegiatan pelatihan ICT. Mitra yang diajak kerjasama merupakan professional yang membantu proses pelaksanaan pelatihan ICT. Dalam hal ini mitra berfungsi sebagai fasilitator pelatihan.

Kompetensi mitra dibidang teknologi pendidikan diharapkan mampu melakukan transfer of knowledge kepada peserta pelatihan sehingga akhirnya guru mampu mengaplikasikan teknologi informasi dalam pengembangan proses pembelajar-an yang efektif dan efesien.

Langkah berikutnya berupa Pelatihan ICT. Tujuan pelatihan pada esensinya merupakan jawaban terhadap permasalahan yang dihadapi oleh individu atau sekelompok orang dalam memperoleh dan meningkatkan kemampuan-kemampuan yang diperlukan untuk melakukan suatu pekerjaan.Dalam suatu organisasi, pelatihan merupakan salah satu upaya yang ditempuh untuk memecahkan permasalahan yang dihadapi atau membantu organisasi supaya dapat berjalan dan mencapai tujuan organisasi secara efektif dan efesien. Tujuan utama pelatihan ini di antaranya adalah: 1) Memperbaiki kinerja guru; 2) Untuk memutakhirkan keahlian para guru sejalan dengan perubahan teknologi; 3) Mengurangi waktu belajar bagi guru baru untuk menjadi kompeten dalam pekerjaannya; 4) Membantu memecahkan masalah operasional; 5) Mempersiapkan guru untuk menyongsong era teknologi; 6) Mengorientasikan 
karyawan terhadap kebutuhan madrasah akan teknologi; 7) Memenuhi kebutuhan-kebutuhan pribadi guru akan teknologi pendidikan.

Jenis pelatihan yang dilakukan adalah pelatihan Microsoft Power Point Interaktif dan pelatihan Microsoft Office Excel (Formulas \& Mail merger). Pelatihan ini diorientasikan supaya guru dapat membuat power point interaktif untuk mapel yang diampu, sehingga proses pembelajaran menjadi lebih menarik serta mampu mengoperasikan microfot office excel dengan baik guna mendukung pekerjaan administratif guru.

Kedua materi pelatihan tersebut berdasarkan request kepala MTs, tujuannya supaya guru dapat proses pembelajaran sehingga lebih efektif. Karena selama ini kompetensi guru terhadap penguasaan ICT belum maksimal. Dengan adanya pelatihan ini guru lebih mampu memanfaatkan teknologi untuk mendukung proses pembelajaran dan penilaian sehingga menjadi lebih baik.

Metode pelatihan yang digunakan meliputi metode praktis dan simulasi. Metode praktis berupa teknik-teknik "on the job trainning" merupakan metode latihan yang paling dominan digunakan dalam pelatihan ini. Guru dilatih untuk membuat produk bahan ajar yang dikemas dalam bentuk power point interaktif dan membuat form penilaian pembelajaran dengan Microsoft office excel, melalui supervisi langsung, seorang "pelatih" yang berpengalaman. Metode ini dilakukan dengan dengan memberikan instruksi teknis secara langsung sesuai tugas pembelajaran yang dilakukan guru, kemudian guru langsung mempraktekannya. Metode ini digunakan terutama untuk melatih para guru tentang cara pelaksanaan pembelajaran yang efektif melalui media teknologi.

Sedangkan Metode simulasi. Dengan metode ini guru peserta latihan melakukan representasi tiruan (artificial).Peserta pelatihan diminta untuk menanggapinya seperti dalam keadaan sebenarnya.

Agar program latihan tidak mengganggu operasi-operasi normal, pihak madrasah menggunakan vestibule trainning. Ruang pelatihan terpisah dengan berbagai jenis peralatan sama seperti yang akan digunakan pada proses pembelajaran sebenarnya. Guru juga diminta untuk membuat bahan ajar dengan power point yang sesuai dengan materi yang diampu oleh guru masing-masing.

Langkah terakhir berupa Evaluasi. Program pelatihan merupakan upaya pengembangan sumber daya manusia.Untuk mengetahui efektivitas dan tingkat ketercapaian dari pelatihan maka dilakukan sebuah langkah yaitu evaluasi.Evaluasi dilakukan bukan hanya pada akhir pelatihan saja karena evaluasi merupakan mata rantai dari sistem pelatihan dimana dilakukan sebelum pelatihan, pada saat pelatihan dan setelah pelatihan. 
Proses evaluasi pada tahap awal yaitu sebelum pelatihan dinamakan dengan need assessment atau mencari tahu keterampilan, dan kebutuhan dari para peserta pendidikan dan latihan serta pengembangan sumber daya manusia. Evaluasi di tahap menengah pada saat dilakukan pelatihan dinamakan monitoring yang bertujuan untuk mencari informasi apakah program pelatihan yang telah disusun berjalan sesuai dengan rencana atau tidak.Dan evaluasi setelah pelatihan dimaksudkan untuk mengetahui tingkat perubahan kinerja dari karyawan atau anggota organisasi setelah mengikuti pelatihan.

Evaluasi menjadi sangat penting untuk dilakukan guna mengukur tingkat ketercapaian dari program pelatihan yang dilakukan sehingga akan memberikan feed back untuk kelangsungan program pelatihan selanjutnya. Peserta merupakan objek dari pelatihan dan akan merasakan hasil dari pelatihan sehinga evaluasi peserta menjadi sangat menentukan keberlangsungan pelatihan selajutnya. Selain peserta yang menjadi ujung tombak keberhasilan atau ketercapaian program pelatihan adalah instruktur yang memberikan materi pelatihan.

Evaluasi program pelatihan ini perlu dilakukan guna melihat efek yang muncul berkaitan dengan reaksi peserta pelatihan terhadap materi dan proses pelatihan, pengetahuan yang diperoleh selama mengikut pelatihan, perubahan perilaku guru, dan perbaikan yang terjadi di madrasah.

Pada pelatihan ini model evaluasi yang digunakan adalah CIPP (Context, Input, Prosess and Product). Context adalah situasi atau latar belakang yang mempengaruhi jenis-jenis tujuan dan strategi pendidikan yang akan dikembangkan dalam sistem yang bersangkutan. Pelatihan ini dilatarbelakangi adanya kondisi guru yang belum maksimal dalam memanfaatkan teknologi informasi dalam mendukung proses pembelajaran dan pekerjaan administratif lainnya.

Input, merupakan sarana/modal/bahan dan rencana strategi yang ditetapkan untuk mencapai tujuan-tujuan pelatihan. Sarana pelatihan ini sebagian besar di backup oleh pihak madrasah dan guru peserta pelatihan itu sendiri. Sarana pelatihan di antaranya adalah LCD, laptop, dan jaringan internet. Secara keseluruhan sarana yang digunakan sudah baik, namun ada beberapa hal yang menjadi catatan di antaranya adalah program power point yang sudah terinstal dalam laptop masing-masing guru berbeda-beda yaitu ada yang versi 2007 dan versi 2010. Esensinya tidak ada perbedaan yang signifikan dengan kedua versi tersebut, namun display yang berbeda menjadikan guru agak kesulitan dalam menggunakan tools yang ada. 
Process, adalah pelaksanaan strategi dan penggunaan sarana/modal/ bahan di dalam kegiatan pelatihan. Seperti yang penulis jelaskan sebelumnya, bahwa strategi atau metode yang diguakan dalam pelatihan ini ada dua yaitu metode praktis dan metode simulasi. Melalui kedua metode ini proses pelatihan bisa berjalan dengan efektif dan efesien. Guru cukup antusias selama mengikuti pelatihan.

Product, adalah hasil yang dicapai baik selama maupun pada akhir pengembangan program pelatihan. Hasil nyata dari pelatihan ini adalah produk dalam bentuk bahan ajar yang dikemas melalui program power point interakif, serta instrument penilaian dalam format power point. Namun yang lebih penting dari itu adalah guru mampu memanfaatkan teknologi bagi pengembangan proses pembelajaran sehingga pada akhirnya tujuan pembelajaran dapat tercapai dengan baik.

\section{PEMBAHASAN PROGRAM}

Perkembangan IPTEK, menuntut guru untuk lebih kreatif dan inovatif dalam mendesain pembelajaran. Jika sarana tersebut telah disediakan oleh sekolah maka sekurang-kurangnya guru diharapkan mampu mengoperasikan dan memanfaatkannya semaksimal mungkin.Namun jika tidak, disanalah dituntut pula ketrampilan guru untuk membuatnya sendiri.Cara guru untuk mendesain pembelajaran yang lebih baik salah satunya dengan memanfaatkan media belajar. Metode dan media pembelajaran yang digunakan oleh guru sangatberpengaruh terhadap hasil proses belajar mengajar karena materi pelajaran dapat disajikan dengan lebih baik, lebih efisien, lebih menarik dan dapat lebih mudah untuk diterima dan dimengerti oleh siswanya.

Keuntungan menggunakan media belajar yang interaktif di antaranya adalah : (1) Memperjelas penyajian pesan agar tidak terlalu bersifat verbalistis (dalam bentuk kata-kata tertulis atau lisan belaka), (2) Mengatasi keterbatasan ruang, waktu, dan daya indera, (3) Penggunaan media pendidikan secara tepat dan bervariasi dapat mengatasi sikap pasif anak didik. Dalam hal ini media pembelajaran berguna untuk menimbulkan kegairahan belajar dan memungkinkan anak didik belajar sendiri-sendiri menurut kemampuan dan minatnya, (4) Sifat unik tiap siswa, lingkungan dan pengalaman yang berbeda, kurikulum dan materi pendidikan ditentukan sama untuk setiap siswa, maka guru akan kesulitan bila harus diatasi sendiri. Lebih sulit lagi bila latar belakang lingkungan guru dan siswa juga berbeda. Masalah ini dapat diatasi dengan media 
pendidikan, yaitu kemampuannya dalam memberikan perangsang yang sama, mempersamakan pengalaman, menimbulkan persepsi yang sama.

Sebelum memutuskan media belajar yang akan digunakan, terdapat beberapa criteria yang harus diperhatikan agar media yang digunakan dapat memberikan hasil yang optimal. Criteria pemilihan media belajar :Pertama, tujuan; harus adanya kejelasan tentang maksud dan tujuan pemilihan media pembelajaran. Apakah pemilihan media itu untuk pembelajaran, untuk informasi yang bersifat umum, ataukah sekedar hiburan saja mengisi waktu kosong.

Kedua, karakteristik dan mutu teknis; setiap media pembelajaran mempunyai karakteristik tertentu, baik dilihat dari keunggulannya, cara pembuatan maupun cara penggunaannya. Memahami karakteristik media pembelajaran merupakan kemampuan dasar yang harus dimiliki guru dalam kaitannya pemilihan media pembelajaran.Disamping itu memberikan kemungkinan pada guru untuk menggunakan berbagai media pembelajaran secara bervariasi.

Ketiga, keadaan siswa; apakah untuk pembelajaran kelompok atau individu, apakah sasarannya siswa TK, SD, SLTP, SMU, atau siswa pada Sekolah Dasar Luar Biasa, masyarakat pedesaan ataukah masyarakat perkotaan. Dapat pula tujuan tersebut akan menyangkut perbedaan warna, gerak atau suara.

Salah satu contoh media belajar audio visual tersebut adalah dengan menggunakan computer atau yang lebih dikenal dengan media pembelajaran berbantuan komputer.Komputer adalah hasil dari kemajuan teknologi elektronika dan informatika yang berfungsi sebagai alat bantu untuk menulis, menggambar, menyunting gambar atau foto, membuat animasi, mengoperasikan program analisis ilmiah, simulasi dan untuk kontrol peralatan. Perkembangan teknologi komputer baik hardware maupun softwarenya saat ini sangat mendukung untuk mengembangkan model pembelajaran edutainment (education entertainment) sekaligus sebagai media pembelajarannya.

Seperangkat komputer multimedia, dan aplikasi dasar program komputer Microsoft Windows dan Microsoft Office dapat kita gunakan untuk mengembangkan model dan media pembelajaran edutainment dengan biaya yang cukup murah. Seperti yang dipergunakan tidak hanya dalam dunia pendidikan tapi juga oleh berbagai kalangan dalam seminar/pertemuan resmi lainnya telah banyak menggunakan program Micrososft Windows dan Microsoft Office sehingga pengembangan model pembelajaran edutainment secara praktis dan sederhana dapat menggunakan media komputer dengan program Microsoft Power Point. 
Mengoptimalkan Microsoft Power Point sebagai media belajar berarti memanfaatkan secara maksimal segala fitur dan sediaan yang dimiliki oleh Microsoft Power Point untuk menunjang kegiatan belajar mengajar.Microsoft Power Point merupakan sebuah software yang dibuat dan dikembangkan oleh perusahaan Microsoft, dan merupakan salah satu program berbasis multi media. Didalam komputer, biasanya program ini sudah dikelompokkan dalam program Microsoft Office. Program ini dirancang khusus untuk menyampaikan presentasi, baik yang diselenggarakan oleh perusahaan, pemerintahan, pendidikan, maupun perorangan, dengan berbagai fitur menu yang mampu menjadikannya sebagai media komunikasi yang menarik.

Aplikasi software Microsoft PowerPoint yang sering digunakan untuk presentasi dapat dioptimalkan penggunaannya dengan memanfaatkan berbagai fasilitas yang dimilikinya seperti hyperlink, insert picture, table, grafik movie ,sound beserta efek animasinya (custom animation) dalam menampilkan gambar bangun, garis, teks dan gambar secara kolaboratif. Pada prinsipnya program ini terdiri dari beberapa unsur rupa, dan pengontrolan operasionalnya.Unsur rupa yang dimaksud, terdiri dari slide, teks, gambar dan bidang-bidang warna yang dapat dikombinasikan dengan latar belakang yang telah tersedia.Unsur rupa tersebut dapat kita buat tanpa gerak, atau dibuat dengan gerakan tertentu sesuai keinginan kita. Seluruh tampilan dari program ini dapat kita atur sesuai keperluan, apakah akan berjalan sendiri sesuai timing yang kita inginkan, atau berjalan secara manual, yaitu dengan mengklik tombol mouse. Biasanya jika digunakan untuk penyampaian bahan ajar yang mementingkan terjadinya interaksi antara peserta didik dengan tenaga pendidik, maka kontrol operasinya menggunakan cara manual.

Berdasarkan sebuah penelitian di kota Madiun dilakukan dengan menggunakan dua macam pembelajaran yaitu pembelajaran pengembangan dan pembelajaran konvensional. Pembelajaran pengembangan adalah pembelajaran yang menggunakan Power Point sedangkan pembelajaran konvensional adalah pembelajaran yang tidak menggunakan Power Point. Hasil penelitian itu adalah pembelajaran dengan menggunakan program Power Point lebih baik daripada pembelajaran tanpa menggunakan program PowerPoint baik dari gaya belajar juga dari prestasi siswa. Selain hasil penelitian tersebut Microsoft Power Point juga memiliki beberapa kunggulan yang membuatnya pantas digunakan sebagai media belajar. Beberapa kelebihan tersebut antara lain : (1) Penyajiannya menarik karena ada permainan warna, huruf dan animasi, baik animasi teks maupun animasi gambar atau foto. (2) Lebih merangsang peserta didik untuk mengetahui lebih jauh informasi tentang bahan ajar yang tersaji. (3) Pesan informasi secara 
visual mudah dipahami peserta didik. (4) Tenaga pendidik tidak perlu banyak menerangkan bahan ajar yang sedang disajikan. (5) Dapat diperbanyak sesuai kebutuhan, dan dapat dipakai secara berulang-uang. (6) Dapat disimpan dalam bentuk data optik atau magnetik. (CD / Disket / Flashdisk), sehingga praktis untuk di bawa kemana-mana.

Ada beberapa hal yang harus diperhatikan dalam pembuatan bahan presentasi dengan menggunakan Microsoft Power Point diantaranya: (1) jangan terlalu banyak tulisan yang ditampilkan, (2) tulisan jangan terlalu kecil karena harus dilihat oleh banyak siswa, (3) seimbangkan antara gambar dan animasi dengan bahan ajar yang ingin disampaikan, (4) Usahakan bentuk presentasi yang interaktif.

Dalam memanfaat Microsoft PowerPoint sebagai media belajar ada beberapa tips singkat yang dapat menjadi acuan sehingga proses belajar menjadi lebih menarik dan memberi kesan elegan dan profesional bagi pendidik :Pertama, pergunakan desain yang konsisten. Hal ini bisa dilakukan dengan menggunakan slide master, sehingga layout, font, bulleting, dan animasi pergantian slide menjadi konsisten hingga akhir presentasi.

Kedua, batasi jumlah baris dalam setiap slide. Jumlah baris dalam slide yang terlalu banyak menyebabkan silde tersebut menjadi terlalu penuh, sehingga teks menjadi kecil-kecil. Akibat yang lebih parah, siswa tidak akan dapat mencerna informasi dalam slide tersebut. Sampaikan poin-poin pokok dalam setiap slide, kemudian gurulah yang harus mengembangkan ketika melakukan presentasi.Ketiga, pergunakan warna teks dan latar belakang yang kontras sehingga dapat dibaca dengan baik oleh siswa.

Keempat, hindari penggunaan animasi dan sound effect yang berlebihan. Animasi dengan diiringi sound effect yang berlebihan justru menyebabkan siswa menjadi tidak dapat berkonsentrasi dengan pelajaran, tapi justru menjadi lebih tertarik dan terpaku dengan animasi yang dihadirkan atau sounds yang diperdengarkan.Kelima, pertimbangkan untuk membuat tombol-tombol yang langsung menghantarkan pada slide tertentu, sehingga bisa melompat maju ataupun mundur tanpa harus melewati silde demi slide (manfaatkan hyperlink).Keenam, satu gambar memberikan puluhan kali lipat informasi, oleh karena itu sedapat mungkin disajikan secara grafis, misalnya tabel, skema, dll.Ketujuh, jika terlalu sering teks saja yang ditampilkan, berikan gambar-gambar ilustrasi yang sesuai untuk membumbui presentasi.

Power Point dapat diibaratkan sebagai boomerang bagi pendidik/presentator dalam memanfaatkannya sebagai media belajar. Jika Power Point dimanfaatkan dengan baik atau benar akan sangat membantu. Terlebih lagi 
jika pendidik dapat memaksimalkan kegunaan dan fungsi dari powerpoint itu sendiri dan menggabungkan dengan aplikasi lain serta kekreatifannya. Kekreatifan dapat dinilai dari segi keindahan, kejelasan dan pengaturan format powerpoint yang dilakukan dengan sedemikian sehingga siswa dapat menyimak dan menerima hasilnya dengan maksimal. Desain yang simple dan "nyambung" dengan bahan ajar yang disampaikan menjadi nyawa kedua dari sebuah Power Point. Karena seringkali dalam banyak presentasi dengan menggunakan Power Point yang lebih banyak diperlihatkan adalah desainnya, sehingga pendidik terkadang melakukan kesalahan kecil yang juga dapat berakibat fatal bagi proses pembelajaran seperti terlalu banyak memberi gambar yang sebenarnya malah akan membuat Power Point tersebut kacau dan tidak "nyambung", pemilihan warna yang kacau sehingga tidak dapat dibaca, font huruf yang terlalu kecil sehingga sulit dibaca, pengaturan yang salah dan masih banyak lagi.

Media belajar dan metode mengajar memang memberi pengaruh yang besar dalam proses belajar mengajar. Salah satu bentuk pemanfaatan media tersebut adalah dengan menggunakan Microsoft PowerPoint.PowerPoint memang memiliki banyak keunggulan dan memberikan banyak kemudahan.Namun dalam pemanfaatannya diperlukan juga kebijakan dan kemampuan dari pendidik untuk memahami, menggunakan dan mengoprasikan segala fitur yang ada pada Power Point secara optimal sehingga mempercepat tercapainya tujuan pembelajaran.

Selain Microsoft Power Ponit, program lainnya yang dapat digunakan untuk membantu pekerjaa administratif guru adalah program Microsoft excel. Microsoft Excel itu adalah salah satu aplikasi dari Microsoft Office yang dirancang untuk mengolah angka/data dan menyajikannya dalam bentuk tabel ataupun grafik.

Microsoft Excel ini berjalan di bawah sistem operasi Windows, selain Microsoft Word aplikasi Microsoft Excel ini juga termasuk salah satu aplikasi yang sering digunakan dalam berbagai bidang, khususnya untuk bidang yang membutuhkan perhitungan matematika yang kompleks.

Microsoft Excel ini memiliki banyak keunggulan, jika kita ingin membuat laporan keuangan yang membutuhkan perhitungan matematika, maka Microsoft Excel dapat dijadikan solusi dalam mengatasi permasalahan tersebut, hal ini dikarenakan Microsoft Excel menyediakan banyak sekali rumus-rumus matematika yang bisa menyelesaikan perhitungan yang kompleks.

Rumus-rumus yang tersedia pada Microsoft Excel misalnya seperti rumus SUM untuk menghitung total nilai, rumus AVERAGE untuk menghitung ratarata, rumus MAX untuk menghitung nilai tertinggi, rumus MIN untuk 
menghitung Nilai terendah, rumus Count untuk menghitung banyak Item, dan sebagainya.

Keunggulan dari rumus-rumus yang ada pada Microsoft Excel ini yaitu bisa digunakan secara otomatis, misalkan pembuatan form penilaian siswa. Jika guru harus menulis nilai siswa secara di buku secara manual tentu saja guru harus memasukan rumus berulang kali karena total nilai siswa ada banyak. Namun dengan aplikasi Microsoft Excel guru tidak perlu melakukan hal itu karena program Microsoft Excel memberikan kemudahan dalam menggunakan rumus.

Jadi guru tidak perlu membuat rumusnya berulang kali, cukup membuat rumus satu kali lalu di drag di kolom atau baris yang diinginkan, setelah selesai mendrag atau menariknya maka secara otomatis total nilai akan terhitung sesuai dengan kolom dan baris yang bersesuian.

Microsoft Excel juga memiliki keunggulan yang lain yaitu dapat menyelesaikan pekerjaan guru secara efektif dan efesien, terutama disaat guru melakukan kesalahan dalam memasukkan data, misalkan guru sudah selesai membuat sebuah penilaian dengan menggunakan rumus SUM untuk menghitung total nilai, namun setelah di periksa ternyata ada data nilai salah satu siswa yang harus diganti. Cara mengatasinya cukup dengan mengganti data yang ingin diganti, tidak perlu mengulangi rumus yang sudah digunakan. Ketika guru selesai menggantinya maka total nilai akan berubah secara otomatis.

Selain itu Microsoft Excel juga memiliki fitur yang cukup canggih yaitu pengurutan data secara otomatis. Cara pengurutannya bisa dilakukan berdasarkan abjad dan bisa juga berdasarkan angka, dalam hal ini pengurutan pada microsoft excel dibedakan menjadi 2 antara lain yaitu : 1 . Ascending atau pengurutan mulai data yang terkecil sampai terbesar. 2. Descending atau pengurutan dari yang besar ke yang kecil. Hal ini sangat membantu guru ketika harus melakukan rangking atau mencari nilai tertinggi dan nilai terendah. Melalui program Microsoft excel tugas administratif guru khususnya dalam pemrosesan nilai siswa menjadi lebih efektif dan efesien.

\section{KESIMPULAN}

Pelatihan ICT ini telah mampu merubah mindside guru dari proses pembelajaran konvensional menjadi pembelajaran yang lebih interaktif. Guru menjadi lebih sadar bahwa kehadiran teknologi tidak dapat dielakan dalam proses pembelajaran. Perkembangan teknologi yang pesat harus bisa dimanfaatkan guru supaya yang muncul adalah dampak positif dan bukan 
sebaliknya. Pemanfaatan teknologi dapat membantu proses pembelajaran menjadi lebih efektif dan efesien serta fun.

Guru harus lebih melek terhadap perkembangan ICT supaya tidak tertinggal. Karena teknologi telah mensasar semua kalangan termasuk siswa.Kondisi yang ada, siswa lebih banyak menguasai teknologi dari pada guru. Guru harus dapat memanfaatkan kondisi tersebut untuk kepentingan proses pembelajaran. Proses pembelajaran melalui media teknologi dirasa lebih menarik di mata siswa daripada proses pembelajaran konvensional.

\section{DAFTAR PUSTAKA}

Munir, 2005.Manajemen Kelas Berbasis Teknologi Informasi dan Komunikasi.Mimbar pendidikan XXIV (2). Universitas pendidikan Indonesia

— 2006.Etika penggunaan Teknologi Informasi dan Komunikasi dalam Pendidikan. Mimbar Pendidikan (2). Universitas Pendidikan Indonesia , 2008.Kurikulum Berbasis teknologi Informasi dan Komunikasi. Bandung: Alfabeta

— 2011.Pembelajaran Jarak Jaub berbasis Teknologi Informasi dan Komunikasi.Alfabeta : Bandung

Natakusumah, E.K, 2002. Perkembangan Teknologi Informasi di Indonesia, Pusat penelitian Informatika-LIPI. Bandung

Priyanto,I.F. 1997. Internet sebagai Basis Pendidikan.Makalah dalam seminar Nasional Pemanfaatan jaring komunikasi pendidikan. Universitas Terbuka

Surya, Muhammad. 2006. Potensi Teknologi Informasi dan Komunikasi dalam Meningkatkan Mutu Pembelajaran.Makalah dalam seminar Pemanfaatan ICT dalam Pendidikan. Pustekom: Jakarta. 